\title{
FUNGSI HUTAN KOTA: KORESPONDENSI MOTIVASI BERKUNJUNG
} DAN KEGIATAN

\section{Urban Forest Functions: \\ Motivational Correspondence of Visiting and Activities}

\section{Riyad Maulana}

Program Magister Rancang Kota, SAPPK, Institut Teknologi Bandung

Email: maulana.riyad@gmail.com

\section{Annisa S. Riska}

Kelompok Keahlian Perancangan Arsitektur, SAPPK, Institut Teknologi Bandung

Email: annisasafira@ar.itb.ac.id

\section{Hanson E. Kusuma}

Kelompok Keahlian Perancangan Arsitektur, SAPPK, Institut Teknologi Bandung

Email: hangsong@ar.itb.ac.id

\begin{abstract}
The high intensity of urban activities tends to make people need to do recreational activities. One of the functions of the urban forest is a recreational place to release the fatigue of the city community from the high intensity of social and economic activities. This research aims to uncover the relationship between the motivation of visiting and activities carried out in urban forests based on respondents preferences. Research was conducted through grounded theory approach with qualitative exploratory methods. Data collection was carried out by distributing open-ended and close-ended online questionnaires, as well as non-random sampling. The collected text data were analyzed with content analysis. The results of the analysis of motivational correspondence between visiting and the activity revealed two functions of the urban forest, namely interactive tourism and educative tourism. Interactive tourists are visitors come with motivation of the quality of the place, whereas their activities are affective and psychomotor. Meanwhile, educative tourists are visitors come with motivational information, whereas their activities are more cognitive aspect.
\end{abstract}

Keywords: activities, preferences, urban forests, visiting motivations

\section{PENDAHULUAN}

Persoalan perancangan kota erat kaitannya dengan pemanfaatan ruang yang aman, nyaman, produktif, dan berkelanjutan. Pemanfaatan ruang inilah yang akan berdampak pada perubahan struktur ekonomi, sosial, budaya, politik, dan perubahan fisik kawasan perkotaan.

Pembangunan fisik kawasan perkotaan diharapkan dapat mensejahterakan masyarakat kota. Namun, dalam perkembangannya dapat menimbulkan permasalahan akibat perencanaan yang kurang memadai (Subarudi, 2014). Pada dasarnya pembangunan infrastruktur di perkotaan bertujuan untuk mendukung kegiatan ekonomi. Dampak pembangunan tersebut dapat menyebabkan terjadinya kerusakan lingkungan, seperti hilangnya ruang terbuka hijau, rusaknya fungsi resapan air, polusi air dan udara (Subarudi, 2014).

Hutan kota merupakan hamparan lahan yang bertumbuhan pohon-pohon yang kompak dan rapat, di dalam wilayah perkotaan. Lokasi hutan kota terletak di tanah negara maupun tanah hak, yang ditetapkan sebagai hutan kota pemerintah setempat (Peraturan Pemerintah Republik Indonesia Nomor 63 Tahun 2002). Fungsi hutan kota yaitu memperbaiki dan menjaga iklim mikro dan nilai estetika, meresapkan air, menciptakan keseimbangan dan keserasian lingkungan fisik kota, serta mendukung pelestarian keanekaragaman hayati Indonesia.

Selain itu, fungsi hutan kota dapat dikelompokkan menjadi fungsi lanskap, fungsi pelestarian lingkungan (ekologi) dan fungsi estetika (Berry, 1976).

Fungsi lanskap meliputi fungsi fisik dan fungsi sosial. Fungsi fisik, yaitu berfungsi untuk perlindungan terhadap angin, sinar matahari, pemandangan yang kurang bagus dan terhadap bau, sebagai pemersatu, penegas, pengenal, pelembut, dan pembingkai. Sedangkan fungsi sosial, yaitu untuk memberikan tempat interaksi sosial yang sangat menyenangkan.
Fungsi pelestarian lingkungan (ekologi), terdiri dari:

a) menyegarkan udara atau sebagai "paru-paru kota",

b) menurunkan suhu kota dan meningkatkan kelembaban,

c) sebagai ruang hidup satwa

d) penyanggah dan perlindungan permukaan tanah dari erosi,

e) pengendalian dan mengurangi polusi udara dan limbah,

f) peredaman kebisingan,

g) tempat pelesterian plasma nutfah dan bioindikator, dan

h) menyuburkan tanah.

Fungsi estetika, yaitu tumbuh-tumbuhan dapat memberikan keindahan dari garis, bentuk, warna, dan tekstur yang ada dari tajuk, daun, batang, cabang, kulit batang, akar, bunga, buah maupun aroma. Hasil penelitian menunjukkan bahwa penilaian hutan kota yang berstrata banyak mempunyai nilai estetika lebih tinggi, daripada hutan kota berstrata dua.

Fungsi lain dari hutan kota adalah fungsi edukatif. Hutan kota memiliki nilai-nilai ilmiah yang dapat menjadi sarana pendidikan dan penelitain berupa laboratorium hidup (Alfian dan Kurniawan, 2010).

Persoalan fungsi hutan kota, yaitu terkait dengan pemanfaatannya sebagai wisata alam. Hal tersebut berdampak pada perubahan lanskap dari hutan kota, terutama kios makanan, oleh-oleh, resto, dan sebagainya. Sehingga, lingkungan alami dari hutan kota jadi menurun karena adanya pembangunan lingkungan binaan yg tidak terkendali (Prastiyo et.al., 2020).

Fungsi hutan kota dalam aspek motivasi berkunjung, kaitannya dengan faktor penarik (pull factor). Fungsi lanskap, pelestarian lingkungan hidup, dan estetika merupakan karakteristik fisik alamiah dari hutan kota. Hal tersebut, dapat menjadi daya tarik tersendiri bagi 
masyarakat perkotaan untuk berkunjung ke hutan kota. Terutama untuk kegiatan relaksasi, mengingat hutan kota memiliki karakter sangat kuat dengan lingkungan alaminya.

Melihat fenomena dan persoalan di atas, maka tujuan dari penelitian ini adalah untuk mengungkap hubungan antara motivasi berkunjung dengan kegiatan yang dilakukan di hutan kota berdasarkan preferensi responden.

\section{METODE PENELITIAN}

Penelitian dilakukan menggunakan pendekatan kualitatif grounded theory dengan metode kualitatif yang bersifat eksploratif. Menurut Creswell (2007), grounded theory merupakan suatu metode penelitian kualitatif dengan tujuan untuk menghasilkan teori dan penjelasan umum dari sebuah fenomena berdasarkan informasi yang diperoleh dari responden. Informasi berupa data tersebut kemudian dianalisis, ditafsirkan, dan disusun menjadi sebuah model hipotesis. Dalam penelitian ini, data yang diperoleh berupa informasi preferensi responde mengenai motivasi berkunjung ke hutan kota dan kegiatan apa saja yang dilakukan di hutan kota.

\section{Metode Pengumpulan Data}

Pengumpulan data dilakukan melalui penyebaran kuesioner daring dengan metode pemilihan sampel nonrandom sampling berupa teknik snowball sampling. Teknik snowball sampling merupakan proses pemilihan sampel dengan memanfaatkan jaringan. Pemilihan sampel dimulai dari whatsapp group dengan anggota yang pernah berdomisili di Kota Bandung, dari mulai teman kuliah S1, S2, dan rekan kerja. Harapannya, dengan dipilihnya responden yang pernah tinggal di Kota Bandung setidaknya pernah berkunjung ke Hutan Kota Babakan Siliwangi. Setelah data diperoleh, sampel tersebut kemudian memilih beberapa individu lain dalam grup yang berbeda untuk menjadi sampel berikutnya. Proses tersebut terus berlanjut hingga jumlah target sampel tercapai. Kuesioner daring yang dibagikan bersifat terbuka (open-ended). Responden diminta untuk menjawab secara bebas dan seluas-luasnya tentang pertanyaan yang diajukan tanpa dibatasi. Dengan metode seperti ini, diharapkan jawaban yang akan didapatkan sesuai dengan pengalaman motivasi berkunjung dan kegiatan yang dilakukan di hutan kota. Selain pertanyaan terbuka, kuesioner juga menggunakan pertanyaan tertutup (closeended) seperti pertanyaan pendapatan, usia mitra, durasi kunjungan/lamanya berkunjung (jam), waktu kunjungan, intensitas kunjungan, dan keinginan berkunjung kembali.

\section{Metode Analisis Data}

Penelitian ini menggunakan tiga tahap analisis data isi (content analysis), yaitu open coding, axial coding, dan selective coding (Creswell, 2007; Corbin, 2008). Tahap open coding merupakan tahap pendefinisian dan pengidentifikasian kata kunci yang diperoleh dari keseluruhan jawaban responden. Pada tahap ini, kata kunci yang memiliki kedekatan makna atau sifat dikelompokkan ke dalam kategori yang sama. Hasil pengelompokan kategori tersebut kemudian disajikan dalam bentuk diagram analisis distribusi. Tahap axial coding merupakan tahap eksplorasi hubungan korespondensi antar kategori. Sementara tahap selective coding merupakan tahap penyusunan model hipotesis berdasarkan hasil hubungan antar kategori pada tahap axial coding.

\section{Karakteristik Responden}

Data yang diperoleh melalui kuesioner daring berasal dari 101 responden dengan rincian 37 orang laki-laki dan 64 orang perempuan. Dominasi usia responden berkisar antara 17 tahun hingga 35 tahun, dengan tingkat pendidikan terakhir beragam yaitu mulai dari SMA hingga S3. Sebagian besar responden merupakan penduduk yang berdomisili Bandung dan Jakarta, namun ada juga responden yang berdomisili selain kota itu, seperti Tangerang, Cimahi, Bekasi, Tasikmalaya, Depok, Sukabumi, Malang, Yogyakarta, Jambi, Pangkalpinang, Kolaka, dan Pekanbaru.

Hutan kota yang pernah dikunjungi oleh responden yaitu Hutan Kota Babakan Siliwangi, Taman Hutan Raya Ir. Djuanda, Hutan Kota Gelora Bung Karno, Hutan Kota UI, Hutan Kota Patriot Bekasi, Hutan Kota Joyoboyo.

\section{HASIL DAN PEMBAHASAN}

\section{Motivasi Berkunjung ke Hutan Kota}

Tahap awal analisis isi, dilakukan open coding untuk mengidentifikasi segmen makna dan kata- kata kunci (kode) yang mewakili segmen makna dari keseluruhan data teks jawaban responden. Beberapa contoh open coding yang diperoleh dari jawaban responden tentang motivasi berkunjung ke hutan kota dapat diamati pada kutipan berikut.

"Ingin menikmati suasana ruang terbuka hijau yang berada di tengah Kota Bandung - Hutan Kota Babakan Siliwangi, Bandung." (Responden no 1)

"Karena hutan kota tersebut menjadi salahsatu opsi untuk liburan menghilangkan penat dan lokasi hutan baksil yang mudah di akses baik oleh kendaraan umum maupun kendaran pribadi - Hutan Kota Babakan Siliwangi, Bandung." (Responden no 19)

"Merupakan ruang terbuka hijau yang mudah diakses, sangat nyaman untuk aktivitas santai dan refreshing Hutan Kota Gelora Bung Karno, Jakarta." (Responden no 33)

Berdasarkan deskripsi tersebut, ditentukan beberapa kata kunci yang mewakili jawaban responden seperti "menikmati suasana", "refreshing", "menghilangkan penat", "mudah diakses", "nyaman", dan "santai".

Temuan kata-kata kunci hasil open coding kemudian dikelompokkan menjadi beberapa kategori. Terdapat lima kategori karakteristik motivasi berkunjung ke hutan kota, yaitu aktivitas, aksesibilitas, atraksi, informasi, dan suasana. Hasil pengkategorian open coding dapat dilihat pada tabel di bawah ini.

Table 1. Hasil Open Coding Motivasi Berkunjung ke Hutan Kota

\begin{tabular}{lll}
\hline No & Kategori & Kata Kunci \\
\hline \multirow{3}{*}{1} & Aktivitas & Rapat koordinasi \\
& & Studi banding \\
\hline & Pekerjaan \\
\hline & & Acara sekolah \\
\hline & & Survata \\
\hline
\end{tabular}




\begin{tabular}{|c|c|c|}
\hline \multirow[t]{12}{*}{ No } & Kategori & Kata Kunci \\
\hline & & Olahraga \\
\hline & & Refreshing \\
\hline & & Jalan-jalan \\
\hline & & Healing \\
\hline & & Main \\
\hline & & Tugas kuliah \\
\hline & & Penelitian \\
\hline & & Silaturahmi \\
\hline & & Camping \\
\hline & & Piknik \\
\hline & & Liburan \\
\hline \multirow{2}{*}{2} & \multirow{2}{*}{ Aksesibilitas } & Dekat \\
\hline & & Mudah diakses \\
\hline \multirow{8}{*}{3} & \multirow{8}{*}{ Atraksi } & Objek daya tarik \\
\hline & & Spot foto \\
\hline & & Terawat \\
\hline & & Landmark \\
\hline & & Forest walk \\
\hline & & Terkonsep \\
\hline & & Fasilitas pejalan kaki \\
\hline & & Area luas \\
\hline \multirow{2}{*}{4} & \multirow{2}{*}{ Informasi } & $\begin{array}{l}\text { Pengetahuan tentang } \\
\text { hutan kota }\end{array}$ \\
\hline & & $\begin{array}{l}\text { Hanya ada satu hutan } \\
\text { kota }\end{array}$ \\
\hline \multirow{10}{*}{5} & \multirow{10}{*}{ Suasana } & Menikmati suasan \\
\hline & & Nyaman \\
\hline & & Santai \\
\hline & & Sejuk \\
\hline & & Asri \\
\hline & & Rimbun \\
\hline & & Udara Segar \\
\hline & & Adem \\
\hline & & Tempat tenang \\
\hline & & Terasa Natural \\
\hline
\end{tabular}

Pada tahap selanjutnya, dilakukan analisis frekuensi dengan metode analisis distribusi untuk mengetahui dominansi frekuensi dari setiap kategori. Hasil analisis frekuensi menunjukkan bahwa kategori paling dominan adalah aktivitas sebesar $66(52,23 \%)$, selanjutnya disusul oleh kategori suasana sebesar 24 (19,35\%), atraksi sebesar $18(14,52 \%)$, aksesibilitas sebesar 14 (11,29\%), dan kategori yang paling tidak dominan adalah informasi sebesar 2 $(1,61 \%)$. Diagram analisis distribusi frekuensi kategori motivasi berkunjung dapat dilihat pada Gambar 1 .

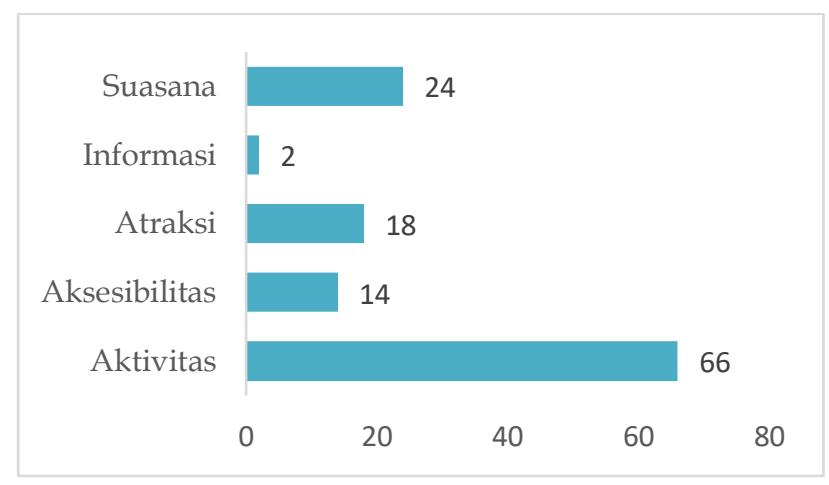

Gambar 1. Analisis Distribusi Frekuensi Kategori Motivasi Berkunjung ke Hutan Kota
Motivasi kebanyakan responden berkunjung ke hutan kota karena melakukan aktivitas, diantaranya yaitu melakukan olahraga, refreshing, wisata, penelitian, dan lain-lain. Aktivitas ini dilakukan oleh responden sebagai upaya melepas penat dari tingginya intensitas kegiatan sosial dan ekonomi di perkotaan, sehingga suasana menjadi motivasi dominan kedua setelah aktivitas. Tentang aktivitas, Berry (1976) mengatakan hutan kota berfungsi sebagai tempat untuk berinteraksi sosial yang menyenangkan. Suasana di hutan kota yang didapatkan dan dirasakan berdasarkan preferensi responden yaitu rasa nyaman, sejuk, asri, udara segar, dilengkapi dengan pepohonan yang rimbun, dan adem. Van den Berg (2010) mengungkapkan bahwa area perkotaan dengan suasana hijau memiliki keterkaitan erat dengan pengembangan kesehatan psikis yang baik dan berkelanjutan.

Atraksi merupakan salah satu daya tarik yang membuat orang berkunjung ke hutan kota (Bachtiar dan Kusuma, 2019). Keberadaan atraksi akan memberikan dampak pada suasana di hutan kota menjadi lebih atraktif dan tidak membosankan.

Selain itu, menurut Permata et. al. (2018) masyarakat di perkotaan akan lebih memilih hutan kota yang berada dekat dengan mereka. Sehingga, aksesibilitas merupakan salah satu alasan penting untuk memudahkan masyarakat mengakses hutan kota (Burton, 1995).

\section{Kegiatan di Hutan Kota}

Untuk mengetahui lebih dalam preferensi fungsi hutan kota, selain pengumpulan data motivasi kenapa berkunjung ke hutan kota, juga dilakukan pengumpulan data terkait kegiatan yang dilakukan di hutan kota. Berdasarkan hasil analisis, didapatkan 9 kategori kegiatan yang dilakukan responden di hutan kota, yaitu wisata, refreshing, olahraga, observasi, membaca jalan santai, interaksi sosial, foto-foto, dan duduk santai. Hasil pengkategorian open coding kegiatan di hutan kota dapat dilihat pada Tabel 2 di bawah ini.

Tabel 2. Hasil Open Coding Kegiatan di Hutan Kota

\begin{tabular}{|c|c|c|}
\hline No & Kategori & Kata Kunci (Kode) \\
\hline \multirow{10}{*}{1} & \multirow{10}{*}{ Wisata } & Jalan-jalan \\
\hline & & Piknik \\
\hline & & Rekreasi alam \\
\hline & & Melihat gua \\
\hline & & Melihat rusa \\
\hline & & Bertamasya \\
\hline & & Menonton pagelaran seni \\
\hline & & Mengunjungi tempat sejarah \\
\hline & & Kuliner \\
\hline & & Wisata alam \\
\hline \multirow{5}{*}{2} & \multirow{5}{*}{ Olahraga } & Olahraga \\
\hline & & Bersepeda \\
\hline & & Jogging \\
\hline & & Tracking \\
\hline & & Hiking \\
\hline \multirow{5}{*}{3} & \multirow{5}{*}{ Foto-foto } & Foto-foto \\
\hline & & Fotografi \\
\hline & & Mencari objek foto \\
\hline & & Mengambil gambar \\
\hline & & Foto human interest \\
\hline \multirow{3}{*}{4} & \multirow{3}{*}{ Refreshing } & Menikmati alam \\
\hline & & Menikmati pemandangan \\
\hline & & Merasakan kesejukan \\
\hline
\end{tabular}




\begin{tabular}{|c|c|c|}
\hline No & Kategori & Kata Kunci (Kode) \\
\hline & & Menikmati udara segar \\
\hline & & Melihat pemandangan \\
\hline & & Refleksi \\
\hline & & Santai \\
\hline & & Menghirup udara segar \\
\hline \multirow{7}{*}{5} & \multirow{7}{*}{ Interaksi sosial } & Diskusi \\
\hline & & Ngobrol \\
\hline & & Kumpulan \\
\hline & & Ngopi \\
\hline & & Belajar \\
\hline & & Gathering \\
\hline & & Nongkrong \\
\hline \multirow{2}{*}{6} & \multirow{2}{*}{ Jalan santai } & Jalan kaki \\
\hline & & Jalan santai \\
\hline \multirow{4}{*}{7} & \multirow{4}{*}{ Observasi } & Observasi situs alam \\
\hline & & Tugas kuliah \\
\hline & & Survey \\
\hline & & Pengamatan \\
\hline \multirow{2}{*}{8} & \multirow{2}{*}{ Duduk santai } & Duduk-duduk \\
\hline & & Duduk santai \\
\hline 9 & Membaca & Membaca \\
\hline
\end{tabular}

Pada tahap selanjutnya, dilakukan analisis frekuensi dengan metode analisis distribusi untuk mengetahui dominansi frekuensi dari setiap kategori. Hasil analisis frekuensi menunjukkan bahwa kategori kegiatan paling dominan adalah wisata sebesar 36 (20,69\%), selanjutnya disusul oleh kategori olahraga sebanyak 31 (17,82\%) dan foto-foto sebanyak $30(17,24 \%)$. Sementara kegiatan yang paling tidak dominan adalah membaca sebesar $2(1,15 \%)$ dan duduk santai sebanyak 4 (2,3\%). Diagram analisis distribusi frekuensi kategori kegiatan di hutan kota dapat dilihat pada Gambar 2.

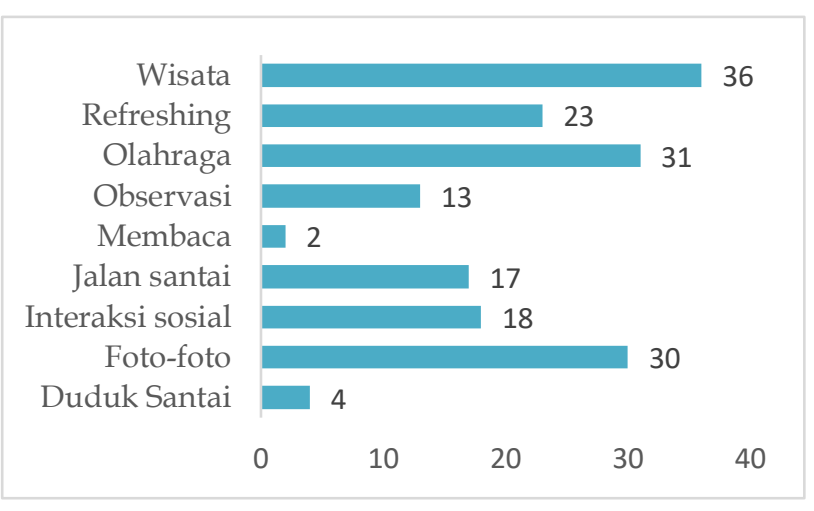

Gambar 2. Analisis Distribusi Frekuensi Kategori Kegiatan di Hutan Kota

Kegiatan di hutan kota yang mendominasi dilakukan oleh responden yaitu wisata, seperti rekreasi alam, jalan-jalan keliling hutan kota, bertamasya, kuliner, melihat daya tarik di hutan kota seperti gua, rusa, tempat sejarah, dan wisata alam. Jenis kegiatan wisata di hutan kota ini merupakan wisata alam, artinya yang dimanfaatkan oleh hutan kota untuk menjadi daya tarik orang berkunjung dan berkegiatan berupa potensi sumber daya alam dan ekosistemnya, baik dalam bentuk asli maupun setelah adanya perpaduan dengan daya cipta manusia (Fandeli et. al., 2004). Berdasarkan Undang-Undang Nomor 10 tahun 2009 tentang kepariwisataan, dijelaskan bahwa daya tarik wisata adalah segala sesuatu yang memiliki keunikan, keindahan, dan nilai yang berupa keanekaragaman kekayaan alam, budaya, dan hasil buatan manusia yang menjadi sasaran atau tujuan kunjungan wisatawan.

Olahraga tidak menjadi prioritas utama dari kegiatan di hutan kota, namun kegiatan berolahraga ini menjadi salah satu kegiatan yang sering dilakukan di hutan kota oleh kebanyakan responden, karena olahraga merupakan suatu kebutuhan dari setiap individu dengan tujuan meningkatkan kebugaran jasmani (Undang-Undang Republik Indonesia Nomor 3 Tahun 2005). Selain itu, dengan potensi keindahan alam yang dimiliki oleh hutan kota, kegiatan berfoto sudah menjadi keharusan dan tidak boleh terlewatkan, karena selain untuk mengabadikan moment, kegiatan berfoto juga bisa menjadi kepuasan tersendiri bagi setiap individu yang telah mengunjungi suatu tempat atau lokasi, dalam hal ini khususnya hutan kota.

\section{Intensitas Kunjungan ke Hutan Kota}

Intensitas kunjungan ini menggunakan data hasil dari pertanyaan tertutup (close-ended), sehingga intensitas kunjungan ini tidak dilakukan proses open coding. Pilihan jawaban dari pertanyaan intensitas kunjungan ke hutan kota terdiri dari empat kategori yaitu $<3$ kali, 3-6 kali, 7-10 kali, dan $>10$ kali. Berdasarkan hasil analisis diagram distribusi frekuensi, kategori intensitas kegiatan yang mendominasi yaitu <3 kali sebanyak 68 (67,3\%), sedangkan yang melakukan kujungan 3-6 sebanyak 21 $(20,8 \%), 7-10$ kali sebanyak 5 (5\%), dan >10 kali sebanyak $7(6,9 \%)$. Diagram analisis distribusi frekuensi kategori intensita kunjungan ke hutan kota dapat dilihat pada Gambar 3.

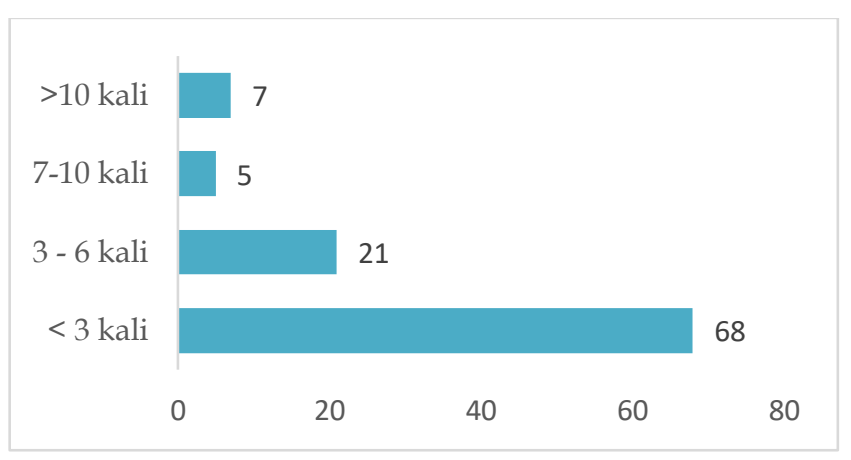

Gambar 3. Analisis Distribusi Frekuensi Kategori Intensitas Berkunjung ke Hutan Kota

\section{Korespondensi Kegiatan dengan Intensitas Kunjungan}

Untuk mengetahui keterkaitan antara kegiatan dengan intensitas kunjungan, pada tahap berikutnya dilakukan axial coding berupa analisis korespondensi. Analisis ini dilakukan dengan menggunakan metode ward hierarchical clustering. Hasil analisis korespondensi kegiatan dan intensitas kunjungan dapat diamati pada Gambar 4

Hasil analisis korespondensi antara kegiatan dengan intensitas kunjungan memiliki nilai signifikansi sebesar $\mathrm{p}$ $=0,0004$, artinya kemungkinan tingkat akurat hubungan antar variabel sebesar 99,96\%. Sehingga, nilai siginifikan ini menunjukan bahwa keterkaitan antar dua variabel tersebut memiliki hubungan yang sangat signifikan dan membentuk tiga cluster. 

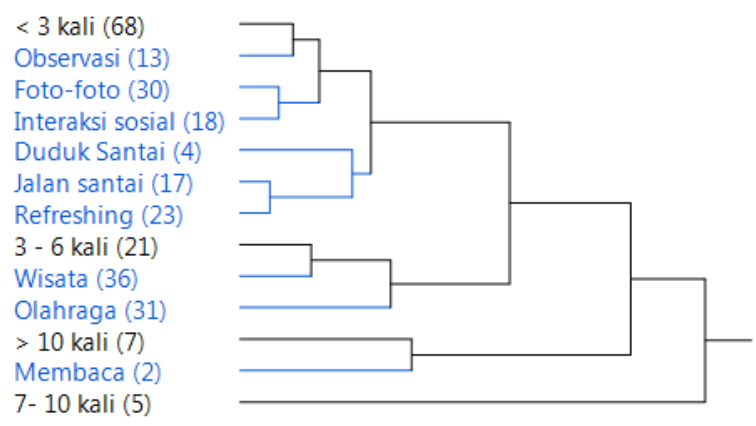

Gambar 4. Korespondensi Kegiatan dan Intensitas Kunjungan

Kelompok pertama yang terbentuk yaitu kelompok intensitas kunjungan rendah ( $<3$ kali) dengan karakteristik responden cenderung melakukan kegiatan afektif atau kegiatan yang berkaitan dengan sikap dan nilai, seperti melakukan observasi, foto-foto, interaksi sosial, duduk santai, jalan santai, dan refreshing. Kelompok kedua yaitu kelompok intensitas kunjungan sedang (3-6 kali) dengan karakteristik responden cenderung melakukan kegiatan psikomotorik atau kegiatan yang berkaitan dengan aktivitas fisik dengan intensitas agak tinggi, seperti wisata dan olahraga. Sedangkan kelompok ketiga yaitu kelompok dengan intensitas kunjungan tinggi ( $>10$ kali) dengan karakteristik responden cenderung melakukan kegiatan kognitif atau kegiatan yang menyangkut aktivitas otak, seperti membaca.

Berdasarkan hasil identifikasi durasi kunjungan, kegiatan membaca dari 2 responden itu memilih durasi kunjungan 1-2 jam dan dilakukan di Hutan Kota Babakan Siliwangi dan Taman Hutan Raya Ir. Djuanda. Sedangkan untuk kegiatan observasi dari 13 responden rata-rata memilih 23 jam. Dapat disimpulkan bahwa kegiatan observasi membutuhkan waktu lebih lama, dibandingkan dengan kegiatan membaca.

\section{Korespondensi Kegiatan dengan Motivasi Berkunjung}

Korespondensi antara kegiatan dan motivasi berkunjung dilakukan untuk mengetahui kebaruan dari fungsi hutan kota. Kemudian pada tahap berikutnya analisis korespondensi antara kegiatan dan motivasi berkunjung, lebih jelasnya hasil analisis dapat diamati pada Gambar 5.

Hasil analisis korespondensi antara kegiatan dengan motivasi berkunjung memberikan nilai signifikansi

Tabel 3. Model Hipotesis Fungsi Hutan Kota

\begin{tabular}{|c|c|c|c|c|c|}
\hline Kegiatan & $\begin{array}{l}\text { Intensitas } \\
\text { Kunjungan }\end{array}$ & Kategori I & $\begin{array}{l}\text { Motivasi } \\
\text { Berkunjung }\end{array}$ & Kategori II & Hipotesis \\
\hline Observasi (13) & \multirow{6}{*}{ <3 kali (68) } & \multirow{6}{*}{ Kegiatan Afektif } & Atraksi (24) & \multirow{8}{*}{ Kualitas Tempat } & \multirow{8}{*}{$\begin{array}{l}\text { Wisata } \\
\text { Interaktif }\end{array}$} \\
\hline Foto-foto (30) & & & Atraksi (24) & & \\
\hline Interaksi Sosial (18) & & & Aktivitas (66) & & \\
\hline Duduk Santai (4) & & & \multirow{4}{*}{ Suasana (18) } & & \\
\hline Jalan Santai (17) & & & & & \\
\hline Refreshing (23) & & & & & \\
\hline Wisata (36) & \multirow[b]{2}{*}{ 3-6 kali (21) } & \multirow{2}{*}{$\begin{array}{c}\text { Kegiatan } \\
\text { Psikomotorik }\end{array}$} & & & \\
\hline Olahraga (31) & & & $\begin{array}{l}\text { Aksesibilitas } \\
(14)\end{array}$ & & \\
\hline Membaca (2) & >10 kali (7) & $\begin{array}{c}\text { Kegiatan } \\
\text { Kognitif } \\
\end{array}$ & Informasi (2) & Informasi & $\begin{array}{c}\text { Wisata } \\
\text { Edukatif }\end{array}$ \\
\hline
\end{tabular}

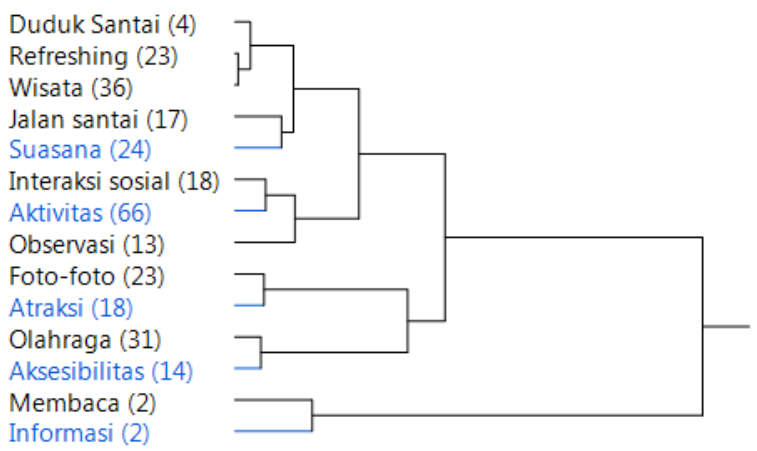

Gambar 5. Analisis Korespondensi Kegiatan dan Motivasi Berkunjung .

sebesar $p=0,171$, artinya kemungkinan tingkat akurat hubungan antar variabel sebesar 82,9\%. Sehingga, nilai siginifikan ini menunjukan bahwa keterkaitan antar dua variabel tersebut memiliki hubungan yang kurang signifikan.

Hasil pengelompokan yang terbentuk pada korespondensi antara kegiatan dengan motivasi berkunjung sebanyak 2 kelompok. Kelompok pertama yaitu kelompok motivasi berkunjung karena kualitas ruang yaitu aksesibilitas, atraksi, aktivitas, dan suasana, dengan karakteristik kegiatan yang afektif dan psikomotorik. Sedangkan kelompok kedua yaitu kelompok informasi dengan kegiatan membaca.

\section{Model Hipotesis}

Pada tahap selanjutnya, dilakukan selective coding berupa penyusunan model hipotesis berdasarkan pola kedekatan antar kegiatan, intensitas kunjungan dan motivasi berkunjung ke hutan kota yang diperoleh pada tahap axial coding. Hasil analisis pola kedekatan dapat diamati pada Tabel 3.

Tabel 3 menunjukan pola kedekatan antar kegiatan, intensitas dan motivasi berkunjung ke hutan kota. Pola kedekatan yang terbentuk berdasarkan pemodelan hipotesis, terdiri dari dua kelompok utama, yaitu wisata interaktif dan wisata edukatif. Wisata interaktif merupakan rangkaian kegiatan yang dilakukan di hutan kota dengan motivasi berkunjung karena kulitas tempatnya, yang terdiri dari atraksi, aktivitas, suasana, dan aksesibilitas. Kegiatan yang dilakukan dalam kelompok wisata interaktif yaitu kegiatan afektif dan psikomotorik. Jenis kegiatan afektif dengan intensitas 
Tabel 4. Keterkaitan Teori dengan Temuan Penelitian

\begin{tabular}{llll}
\hline $\begin{array}{l}\text { Peraturan Pemerintah Republik Indonesia } \\
\text { Nomor 63 Tahun 2002 }\end{array}$ & Berry, 1976 & $\begin{array}{l}\text { Alfian dan } \\
\text { Kuniawan, 2010 }\end{array}$ & $\begin{array}{l}\text { Hasil Penelitian, } \\
2020\end{array}$ \\
\hline $\begin{array}{l}\text { Menciptakan keseimbangan dan keserasian } \\
\text { lingkungan fisik kota, meresapkan air, }\end{array}$ & Fungsi lanskap & & \\
\hline $\begin{array}{l}\text { Mendukung pelestarian keanekaragaman } \\
\text { hayati Indonesia, memperbaiki dan } \\
\text { menjaga iklim mikro }\end{array}$ & Fungsi ekologi & & \\
\hline Nilai estetika & Fungsi estetika & & Wisata Edukatif \\
\hline- & - & $\begin{array}{l}\text { Fungsi edukatif } \\
\text { (pendidikan dan } \\
\text { penelitian) }\end{array}$ & \\
\hline- & - & - & Wisata Interaktif \\
\hline
\end{tabular}

kunjungan rendah terdiri dari observasi, foto-foto, interaksi sosial, duduk santai, jalan santai, dan refreshing.

Sedangkan jenis kegiatan psikomotorik dengan intensitas kunjungan sedang terdiri dari wisata dan olahraga. Wisata edukatif merupakan serangkaian kegiatan yang dilakukan di hutan kota dengan motivasi berkunjung karena informasi. Kegiatan yang dilakukan dalam elompok wisata edukatif yaitu kegiatan kognitif. Jenis kegiatan kognitif dengan intensitas kunjungan tinggi hanya terdiri dari satu kegiatan yaitu membaca.

Tingkat dari sikap terhadap tempat dapat diukur dari banyak cara. Karakter tempat, kesan terhadap tempat, dan aktivitas (Najafi dan Shariff, 2011) yang dilakukan dalam penelitian ini adalah hal-hal yang yang berkaitan dengan aktivitas atau kegiatan, karena hutan kota merupakan salah satu ruang terbuka hijau di lingkungan perkotaan yang dapat menjaga kelestarian, keserasian dan keseimbangan ekosistem yang meliputi unsur lingkungan, sosial dan budaya.

Melihat hasil dari penjelasan tersebut, maka diperlukan mapping teori untuk mengetahui kedudukan hasil dari penelitian ini dengan penelitian terdahulu. Model hipotesis menunjukan selain sebagai kawasan wisata edukatif, hutan kota juga berfungsi sebagai wisata interaktif. Interaktif dalam hal ini yaitu adanya hubungan timbal balik, baik manusia dengan manusia, manusia dengan alam, dan bahkan alam dengan alamnya itu sendiri. Sehingga, hutan kota berfungsi sebagai ruang rekreasi publik, sarana pembelajaran, tempat untuk mengisi waktu luang, dan tempat untuk mengurangi stress (Lestari et. al., 2005). Untuk lebih jelasnya dapat dilihat pada Tabel 4 .

\section{SIMPULAN}

Hasil temuan dari penelitian ini menunjukan adanya hubungan antara kegiatan, intensitas dan motivasi berkunjung. Hubungan tersebut membentuk dua kelompok besar motivasi responden untuk berkunjung ke hutan kota, terdiri dari kelompok wisata interaktif dan wisata edukatif. Kelompok wisata interaktif ini memiliki intensitas kunjungan rendah sampai sedang, kegiatan yang dilakukan bersifat afektif dan kognitif. Sedangkan kelompok wisata edukatif, memiliki intensitas kunjungan lebih tinggi artinya lebih sering dibandingkan dengan intensitas kunjungan kelompok wisata interaktif, dan kegiatan yang dilakukan bersifat kognitif.
Penelitian ini masih memiliki beberapa kekurangan, walaupun secara pendekatan dilakukan dengan grounded theory. Data yang digunakan kurang representatif karena metode yang digunakan untuk pengumpulan data yaitu dengan metode non-random sampling. Sehingga untuk meningkatkan reliabilitas dan tingkat keakuratan data, perlu dilakukan penelitian dengan metode pengumpulan data random sampling, agar data lebih representatif. Mengenai keakuratan data, terutama dalam hal perbedaan persepsi hutan kota antara responden dengan apa yang ditetapkan oleh peraturan, khususnya terkait fungsi hutan kota.

Rekomendasi lainnya yaitu mengenai penelitian lanjutan, perlu adanya pengintegrasian mengenai karakteristik alami hutan kota dengan kegiatan responden, agar fungsi hutan kota menjadi sebuah perwujudan dari ruang terbuka hijau yang ideal, dalam mengakomodir ekosistem yang berada di dalam sebuah kota.

\section{DAFTAR PUSTAKA}

Alfian, R., Kuniawan, H. 2010. Identifikasi Bentuk, Struktur, dan Peranan Hutan Kota Malabar Malang. Buana Sains, 10 (2), 195-201

Bachtiar, J. C. U., Kusuma, H. E. 2019. Pengelompokan Pengunjung Berdasarkan Durasi Kunjungan dan Karakteristik Taman: Relaksasi, Pelarian, dan Penikmat. Jurnal Lanskap Indonesia, 11(1), 11-16

Berry, D. 1976. Preservation of Open Space and the Concept of Value. American Journal of Economics and Sociology, 35 (2), 113-124. United States: WileyBlackwell.

Burton, R. 1995. Travel Geography. London: Pitman Publishing.

Creswell, J. W. 2007. Qualitative Inquiry and Research Design: Choosing among Five Approaches (2nd ed.). London: SAGE Publications

Corbin, J., Strauss, A. 2008. Basics of Qualitative Research: Techniques and Procedures for Developing Grounded Theory (3rd ed.). Thousand Oaks, CA: Sage.

Fandeli, C., Kaharudin, Mukhlison. 2004. Perhutanan Kota. Fakultas Kehutanan Universitas Gadjah Mada: Yogyakarta.

Kementerian Pariwisata. 2009. Keputusan Menteri Nomor 10 Tahun 2009 tentang Kepariwisataan. 
Lestari, R. A., Jaya, I. N. S. 2005. Penggunaan Teknologi Penginderaan Jauh Satelit dan SIG untuk Menentukan Luas Hutan Kota: (Studi Kasus di Kota Bogor, Jawa Barat). Jurnal Manajemen Hutan Tropika 11 (2), 56-69

Najafi, Shariff. 2011. The Concept of Place and Sense of Place in Architectural Studies. World Academy of Science, Engineering and Technology 56, 1100-1106

Pemerintah Republik Indonesia. 2002. Peraturan Pemerintah Republik Indonesia Nomor 63 Tahun 2002 tentang Hutan Kota

Pemerintah Republik Indonesia. 2005. Undang-Undang Republik Indonesia Nomor 3 Tahun 2005 tentang Sistem Keolahragaan Nasional.

Permata, N. D, Syartinilia, Munandar, A. 2018. Pemanfaatan Hutan Kota di Wilayah Jakarta Timur
Sebagai Kawasan Rekreasi Masyarakat Kota. Jurnal Lanskap Indonesia, 10 (2), 47-55

Prastiyo, Y. B., Kaswanto, R. L., Arifin, H. S. 2020. Plants Diversity of Agroforestry System in Ciliwung Riparian Landscape, Bogor Municipality. IOP Conference Series: Earth and Environmental Science, 477, 012024. https://doi.org/10.1088/1755$1315 / 477 / 1 / 012024$

Subarudi, Samsoedin, I., Sylviani, Syahadat, E., Ariawan, K., Suryandari, E. Y., dan Panjaitan, J. H. 2014. Sintesis Penelitian Integratif Pengembangan Hutan Kota pada Lanskap Perkotaan. Bogor. Kementerian Lingkungan Hidup dan Kehutanan

Van den Berg, A. E., Maas, J., Verheij, R. A, Groenewegen, P. P. 2010. Green Space as A Buffer Between Stressful Life Events and Health. Soc Sci Med, 70(8), 1203-1210 